\title{
Palaeoenvironmental control on distribution of crinoids in the Bathonian (Middle Jurassic) of England and France
}

\author{
Aaron W. Hunter and Charlie J. Underwood \\ Acta Palaeontologica Polonica 54 (1), 2009: 77-98 doi:http://dx.doi.org/10.4202/app.2009.0109
}

Bulk sampling of a number of different marine andmarginalmarine lithofacies in theBritish Bathonian has allowed us to assess the palaeoenvironmental distribution of crinoids for the first time. Although remains are largely fragmentary, many species have been identified by comparison with articulated specimens from elsewhere, whilst the large and unbiased sample sizes allowed assessment of relative proportions of different taxa. Results indicate that distribution of crinoids well corresponds to particular facies. Ossicles of Chariocrinus and Balanocrinus dominate in deeper-water and lower-energy facies, with the former extending further into shallower-water facies than the latter. Isocrinus dominates in shallower water carbonate facies, accompanied by rarer comatulids, and was also present in the more marine parts of lagoons. Pentacrinites remains are abundant in very high-energy oolite shoal lithofacies. The presence of millericrinids within one, partly allochthonous lithofacies suggests the presence of an otherwise unknown hard substrate from which they have been transported. These results are compared to crinoid assemblages from other Mesozoic localities, and it is evident that the same morphological adaptations are present within crinoids from similar lithofacies throughout the Jurassic and Early Cretaceous.

Key words: Echinodermata, Crinoidea, lithofacies, palaeoecology, Jurassic, Bathonian, England, France.

Aaron W. Hunter [aaron.hunter@ucl.ac.uk] and Charlie J. Underwood [c.underwood@bbk.ac.uk], Research School of Earth Sciences, Birkbeck and University College London, Gower Street, Bloomsbury, London, WC1E 6BT, UK.

This is an open-access article distributed under the terms of the Creative Commons Attribution License (for details please see creativecommons.org), which permits unrestricted use, distribution, and reproduction in any medium, provided the original author and source are credited. 
Forif Full text $(658.1 \mathrm{kB})$ 